\title{
J.M. Coetzee's Diary of a Bad Year: Between Essay Writing and Fiction
}

\section{Richard Samin}

\section{Q OpenEdition}

Journals

Electronic version

URL: https://journals.openedition.org/ces/8640

DOI: $10.4000 /$ ces. 8640

ISSN: 2534-6695

Publisher

SEPC (Société d'études des pays du Commonwealth)

\section{Printed version}

Date of publication: 1 September 2009

Number of pages: $45-53$

ISSN: 2270-0633

\section{Electronic reference}

Richard Samin, "J.M. Coetzee's Diary of a Bad Year. Between Essay Writing and Fiction", Commonwealth Essays and Studies [Online], 32.1 | 2009, Online since 23 December 2021, connection on 17 February 2022. URL: http://journals.openedition.org/ces/8640 ; DOI: https://doi.org/10.4000/ces.8640

\section{(c) $($ †) $\ominus$}

Commonwealth Essays and Studies is licensed under a Licence Creative Commons Attribution - Pas d'Utilisation Commerciale - Pas de Modification 4.0 International. 


\section{J.M. Coetzee's Diary of a Bad Year: Between Essay Writing and Fiction}

Diary of a Bad Year is a hybrid book combining a series of genuine essays with fictional narratives written in the form of a diary and confessional memoirs. With the combination of these different discursive strands and narrative voices on the same page Coetzee tries to experiment with a new pattern of reading. The unusual form of the novel distorts the reader's conventional perpective on plot and characters while it sustains the narrator's reflections about the questions of identity and authority involved in the very act of writing. The questions which the article addresses are whether the introduction of topical essays in Coetzee's book merely serves to provide a substantial thematic background to the fictional strands of the novel or whether the textual composition of the novel constitutes an experimental essay to probe into such questions as narratorial authority, the ethics of writing and the identity of the writing self.

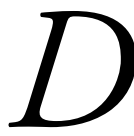

iary of a Bad Year "takes a daring form", as one reviewer puts it (Wood). Literarily innovative and challenging, it is above all a hybrid and polyphonic novel composed of a series of genuine and often penetrating essays on contemporary issues and of fictional diary-like accounts of personal impressions by three different characters, including the narrator, whose lives are intertwined in a bittersweet romance. The contrapuntal association of three different narrative strands places the reader in an awkward position since he has to choose between several reading strategies and leaves him wondering how he can link them meaningfully. The questions which this paper wants to address are whether the introduction of topical essays in Coetzee's book merely serves to provide a substantial thematic background to the fictional parts of the novel or whether they are instrumental in probing into such questions as discursive agency and the identity of the writing self. Does the fiction serve to undermine the assumed authority of the academic and essayistic voice or do the essays need the voice of an ostensibly fictionalised, self-conscious and self-questioning narrator to paradoxically validate the ideas and pronouncements they contain? In other words does the hybrid composition of the novel suggest that the difference between the essayistic self and the fictional self is not ontological but discursive?

Diary of a Bad Year (2007) is an experimental novel written in a form analogous to a music score with three different sections running concurrently on each page formally separated by a horizontal line. The book is divided into two parts: the first one, entitled "Strong Opinions 12 September 2005 - 31 May 2006" and the second part "Second Diary". The space in the upper third of each page is devoted to a series of 31 formal essays in the first part, and 24 texts consigning more personal impressions in the second. The lower two thirds (except for the first five sections and the thirty first of "Strong Opinions") are occupied by the 
narrator's typist's diary. The main protagonist, the author of the essays - in several respects a version of J.M. Coetzee (a white South African, a former academic and a vegetarian, the author of Waiting for the Barbarians ${ }^{1}$ ) -, is an ageing and distinguished novelist, newly resident in Australia, variously called C, El Señor C, J.C. or Juan. At the beginning of the novel he falls in love with a young Filipina, Anya, he meets in the laundryroom. She is a lively, Lolita-like figure who lives in the same block of flats with her lover, Alan, a financial consultant, but, instead of declaring himself or making passes at her, he recruits her to type out the manuscript of his essays for a collection to be published in Germany, along with those of five other major novelists, under the title Strong Opinions.

The essays, which feature on the upper third of each page, are written in an expository prose with clarity, poise and fluidity, and they are in many respects redolent of Coetzee's prose style in his collection of essays like Doubling the Point (1992), Giving Offense (1996) or Stranger Shores (2001). They display a wide range of opinions on the present state of the world, ranging from political philosophy (the origin of the state, anarchism, democracy, Machiavelli), to contemporary politics (the Second Gulf War, terrorism, Al Qaida, Guantanamo, national shame), and miscellaneous topics (the body, avian influenza, universities, intelligent design, probabilities, raiding in South Africa, Harold Pinter, music, Tony Blair, left and right, authority in fiction, after-life). Beyond their topicality and thematic diversity the essays mostly evince the narrator's ethical concerns and his feeling of unbearable shame "at the Bush administration's connivance at torture" (Woods). The overall tonality of the essays is rather left-leaning, and they occasionally ring with a more cynical and provocative edge which Senor $\mathrm{C}$ qualifies as "pessimistic quietistic anarchism" (203). They are often polemical and accusatory, explaining how the West has undermined and betrayed its own ethical principles while it seeks to excuse or conceal its exactions and contradictions with pseudo-rational arguments especially as regards its fight against terrorism. The implicit idea which underpins most of the essays is that the kind of ethics which the West seeks to impose on the rest of the world is flawed and has become irrelevant today largely on account of the fact that it has failed to learn how to accept the Other. The narrator thus comes up with a few provocative statements like "democracy is totalitarian" (15), or establishes a parallel between American bombings and Islamist terrorist attacks asserting that "dropping bombs from high altitude upon a sleeping village is no less an act of terror than blowing oneself up in a crowd" (21), or pointing out, tongue in cheek, that some American prosecutors, encouraged by the Administration's paranoia on terrorism, are prone to overinterpret suspect behaviour as a result of having been exposed to post-modernist literary theories, because "they were taught that in criticism suspiciousness is the main virtue" (33). Although one is tempted to assign these opinions to Coetzee himself nothing

1. Waiting for the Barbarians is J.M. Coetzee's third novel, published in 1980, and it won him the Booker Prize. 
warrants it: the voice we hear, like the others, is first of all a voice created by the texts themselves, proceeding from the very act of enunciation.

The fictional texts, written in the form of diaries, make up the plot proper and concurrently display the narrator's reflections on his restrained amorous relation with Anya, on the part she plays in his own writing and how he responds to her naïve queries or her suggestions as to what topics he should write on. In the first five sections only the narrator's reflections and the tenor of his conversations with Anya are reported in the form of narrated or indirect speech. From the sixth section onwards, the introduction of Anya's impressions pushes the narrator's text one notch higher to the middle third of the page. Anya's diary contains her own impressions and the conversations she has with the narrator on the one hand and with her lover on the other, reported in indirect speech, but they are couched in a register which is generally informal when it is not downright crude. Altogether four voices are heard on almost each page: the essayistic voice, the fictional narrator's voice, Anya's and her lover's. The two fictional strands converge to narrate the mute and subtle sexual game that goes on between the two main protagonists. Senor $\mathrm{C}$ is sexually attracted by Anya but given his age he knows that it will simply boil down to what he calls "a metaphysical ache" (7) or an ache of "a post-physical kind" (13). The way he looks at her betrays him and Anya self-consciously teases him: "When I make my silky moves I can feel his eyes lock onto me. That is the game between him and me. I don't mind. What is your bottom for? Use it or lose it" (28). However as the story unfolds, this game tails off into mutual respect and consideration proceeding from their shared involvement in the production of texts and Anya's gradual capacity to articulate ideas through her better mastery of language under the influence of Senor C. Their final parting is fraught with restrained emotion.

The second part of the novel, "Second Diary", introduces a slight compositional variation. The upper part is now occupied by the narrator's "softer opinions" by contrast with his "strong opinions". The central third of the page is left blank until the fifth section, while the lower third is still occupied by Anya's diary. It is a lengthy relation of the dinner which Senor C had offered to Anya and her lover Alan to celebrate the completion of his manuscript. During the dinner, Alan, who has always been contemptible of Senor $\mathrm{C}$ and resented his growing influence on Anya and her interest in his work, took on his host and grossly humiliated him to the dismay of his girl-friend who immediately decided to part from him. The detailed account of this disastrous evening runs continuously through twenty-two sections out of twenty-four. From the fifth section onwards, the central third of the page records Senor C's conversation with Anya as the latter comes to apologize for her lover's behaviour on the morning following the dinner. She tells him how she has appreciated working with him, praises his honesty and informs him of her decision to leave her lover and return to her mother's home in Queensland. From section 13 to the end, the central part of the page is occupied by a letter from Anya informing Senor C of new developments in her life. In the last two chapters, the 
bottom third of each page continues Anyas diary in which she consigns the steps she has taken with Senor C's neighbour, Mrs Saunders, to make sure that, should anything befall him, he should not be left alone, confessing she knew he was in love with her "in his old man's way" (226) and that on his last hour she would fly to Sydney "to hold his hand tight and give him a kiss on the brow" (227).

The content also changes: most of the essays contained in "Second Diary" deal with more ordinary topics than in the "Strong Opinions" section. They cover a fairly wide choice of topics ranging from reflections on a dream, on the narrator's father, on eroticism, to writing, language, J.S. Bach and Dostoevsky, adopting a more narrow focus and evincing more personal and intimate impressions than in the essays of "Strong Opinions". Besides the narrator does not sound as categorical and all-knowing as in the first part as though he had heeded his typist's suggestions that he should write something more likely to attract an audience: "why not write reminiscences of your love life? That is what people like best - gossip, sex, romance, all the juicy details" (67) or something more personal like "confessions" or "memoirs" instead of essays, bringing to mind Susan Barton's concern with her own writing in Foe. ${ }^{2}$ In spite of the ostensible division that separates the essays or the personal impressions from the fictional diary-like sections, there are subtle intertwinings. Occasional words, phrases and allusions which more appropriately belong to Senor C's register ironically migrate from the top of the page to the bottom in Anya's and Alan's discourses to create burlesque effects: Anya once refers to the political notion of "common decency" (48) while Alan, whose speech is usually blunt and crude, summons the philosophies of Kant and Nietzsche to justify his vision of the world or peppers his speech with mythical figures like Orpheus and Eurydice (78) to vindicate his neo-liberal stance. Together they also discuss about some of the topics analysed in Senor C's essays.

The questions the reader asks himself or herself when confronted with the textual layout of the novel is how to link the different parts together and what strategy to choose to read it. He or she is confronted with three possible choices: they can choose to read each page entirely but their reading will be discontinuous since they are compelled to register facts belonging to different generic frames dealing with different topics. The second choice would consist in reading through the essays first, jumping from page to page in order to grasp the gist of their content and then turn the pages back in order to read through the two fictional strands. The third mode of reading would be an aleatory combination of both methods.

Each page in fact offers a dialogical space in which personal and general issues are debated first in the essays and then between the main protagonists and inside each narrator's consciousness to the extent that the writing becomes the vehicle of orality and rings with each speaker's idiosyncracies in terms of syntax, vocabulary and register. The narrative status of the essays is ambiguous on two counts:

2. Susan Barton is the main narrator and protagonist in Foe. 
temporal and logical. First if one analyses their relation to the fictional narratives, they are posterior to them since they are the concrete end product of a process which originates in the fiction. Their juxtapositon on the page dissimulates a temporal gap. Second, although the formal division of the page separates them from the texts below, they are in fact implicated in them, or more precisely, they form the outside of the inside, both proceeding from the same substrate. This common substrate can be broadly defined as the process whereby enunciating instances appropriate language and emerge as speaking subjects.

The reader can legitimately wonder whether, on the face of it, the novel is a mere literary game, a postmodern intellectual teasing. It is not entirely so. Through this experimental form of writing, Coetzee in fact harps once again on one of his major concerns: what is it that happens when one writes? Who speaks when writing and how can one be absolutely sure that it is the true self that speaks when one writes?

For readers familiar with Coetzee's novelistic productions over the last few years, the combination of fiction and non-fiction is not new. He has used it extensively with the Elizabeth Costello pieces, some of which, if not most, were put together, with minor adaptations in his novels, The Lives of Animals (1999) and Elizabeth Costello (2003). These texts, which contain conferences delivered by a fictional character, a middle-aged Australian novelist, Elizabeth Costello, within a narrative frame, were actually delivered by Coetzee as genuine lectures in American universities, at Bennington University in 1996 and Princeton University in 1997. The reading of these lectures by Coetzee were like a mise en abyme of the situations represented in the texts of the lectures and in the novels: within the context of a genuine act of communication, he transposed verbal imagery situation into a performative speech act, thus endowing his heroine, Elizabeth Costello, with a living voice.

We do not have a similar mirror-like effect in Diary of Bad Year. The essential difference is that the bulk of the texts which make it up are not meant to be heard but read. Whereas the Costello pieces were fictions delivered as genuine lectures, the essays of Diary of a Bad Year, owing to their topographical prominence, seem to supersede the fictional parts: they are borderline texts. They are virtually outside the novel since they are meant to constitute a separate collection of essays entitled Strong Opinions. The blurring of generic differences between essays which deal with contemporary issues and are implicitly addressed to an audience likely to be interested in this type of writing and the fictional world with which they are produced, baffles conventional reading habits. Unlike the Costello lectures which were delivered to a captive audience, the reader of Diary of a Bad Year is free to ignore the essays if he so wishes although it is not easy to dismiss them since their overwhelming presence precludes a linear reading and obliges the reader to choose a strategy of reading, as we have seen above. However, like the Costello lectures, their status remains ambiguous since they deal with external and topical matters while their origins are located in an internal and fictionalised world. Diary of a 
Bad Year in fact plays with the notion and perception of authorship, it is a game which masks and blurs the true identity of the narrators in a bid to dissolve the centrality or essence of the self, to thwart the temptation to assign a definite and permanent identity to the narrating instance by breaking down the author's voice into as many fictional voices as possible, including one which may sound more "real" than the others.

The question of identity and particularly of discursive identity is not new with Coetzee. Thus, in an article published in 1977, "Achterberg's 'Ballade van de Gasfitter': The Mystery of I and You", he clearly asks the question; "I want to begin by asking not what I and You signify but how they signify in the field of language and in the field of the poem" (Coetzee, Doubling 70). Likewise we could proceed with asking how the different narrative instances interact and signify in Diary of a Bad Year. Several first person voices are distinctly heard in the novel but owing to the narrative apparatus and the frequent use of indirect speech or free indirect speech they seem to move freely from one to the other. As Coetzee points out: "all versions of the I are fictions of the I" (Coetzee, Doubling 75).

The recurrent concern manifested by the different protagonists of the novel is that of self-consciousness, self-distanciation, the desire to look at oneself from an external stance, establishing a gap, a distance, a split within the self, in short a concern with their subjectivity. To do so he invites the reader to pay attention to the correspondances and echoes that link the different textual strands together. The dialogical pattern of narrating and speaking voices is paralleled by shifts of points of view. Thus Anya tries to imagine what the old man might have felt when he first saw her: "As I pass him carrying the laundry basket, I make sure I waggle my behind, my delicious behind, sheathed in tight denim. If I were a man, I would not be able to keep my eyes off me" (25). Likewise, some time later Senor C imagines what she might have thought or said about him: "and in an intuitive way she knew about it, knew that in the old man in the plastic chair in the corner there was something personal going on, something to do with age and regret, and the tears of things" (7). This nomadic shift between speaking subjects and narrative instances sustains the rhythm of the text with a constant back and forth movement which feeds their own subjectivity.

In an article on the subjectivity in language, Emile Benveniste point out that it is in and through language that man constitues himself as subject: "subjectivity is the speaker's capacity to posit himself as 'subject' " (259). He further adds that "the possibility of self-consciousness is only felt by contrast" (260) that is in a dialogical relation. In this novel Coetzee seems to pursue and implement on a larger scale the notion of "middle voice" he analysed in a short note ("A note on writing") published in 1984. The "middle voice" is to "do-writing" with reference to the self, "to make oneself the centre of the action of la parole [...] to leave the writer inside the writing not as a psychological subject but as the agent of the action" (Coetzee, Doubling 94). It is precisely the effectivity of the "middle voice" which Coetzee explores narratively and dialogically in Diary of a Bad Year, thus 
pursuing what Derek Attridge calls "the haunting illusion [...] that there is an unbridgeable distance between the person who lives in the world and the person or impersonal force that produces the word" (Attridge 200).

The "idea of the impersonal force that produces the word" is broached in early in the novel in a conversation with Senor C reported by Anya: "Stories tell themselves, they don't get told he said [...] Wait for the story to speak for itself" (55). In the penultimate essay of the first part entitled "On authority in fiction", the narrator self-consciously claims that the voice of the narrator, the one "that speaks the first sentence [...] has no authority at all" (149), and, he continues, "on the novelist author lies the onus to build up, out of nothing, such authority" (149). According to him "the authority of the author has never amounted to anything more than a bagful of rhetorical tricks" (149) and yet, he contends, "what the great authors are masters of is authority" (151). What does authority mean then? He tentatively answers that "it can be obtained only by opening the poet-self to some higher force, by ceasing to be oneself and beginning to speak vatically" (151).

Taking one's cue from this remark, one may wonder if it is not what Coetzee is trying to do in this novel: to "cease to be oneself". Gilles Deleuze claims that writing is an impersonal and an a-subjective arrangement and that the use of the first two personal pronouns "I" and "you" does not suffice to create the frame conditioning literary enunciation (13). "Literature," he adds, "only begins when there arises in us a third person which deprives us of the power to say "I" (ibidem). There are two ways to cease to be oneself: i) to probe to the limits "one's capacity to enter imaginatively into a different mode of existence" (Attridge 202), or ii) to wear masks which the narrator encapsulates in the Latin phrase "Larvatus prodeo", meaning "I advance masked (or bewitched)". It is now obvious to many readers that Coetzee uses masks in his fiction, or reverses the roles of author and character as he does in Foe or in his Nobel Laureate lecture "He and His Man" (Coetzee 2003). However, he does not engage in this postmodern playfulness for the sake of teasing the reader with "fictional truths and truthful fictions" (Attridge 199) but to probe into the ethics of writing.

The question of an author's capacity to enter into a different mode of existence was raised by Elizabeth Costello in her lecture "The Philosophers and the Animals" in the following terms: "If I can think my way into the existence of a being who has never existed, then I can think my way into the existence of a bat or a chimpanzee or an oyster, any being with whom I share the substrate of life" (Coetzee, The Lives 49), and for that matter into the existence of such characters as Anya, a shrewd, attractive and somewhat provocative young woman, or Alan, a blunt liberal-minded materialist. Thus the co-presence of different voices, imaginary and not so imaginary, within the confines of the novel are mere avatars, or, more precisely, events brought about by the force or energy of this "substrate of life". To venture into the life experience of another existence thus boils down to an 
opening out onto what is beyond oneself, unknowable, an experience which, in phenomenological terms, would be described as the advent of the Other.

When the narrator, in one of his personal "softer opinions" in the second part of the book, notes that "at times, as I listen to the words of English that emerge from my mouth, I have a disquieting sense that the one I hear is not the one I call myself. Rather, it is as though some other person (but who?) were being imitated, followed, even mimicked" (195), he questions the concept of a closed, well-defined and irrefragable identity in fiction. The voice that is heard is not that of a firmly established and transcendental subject but one that is immanent to the language through which he announces himself. Senor C, in his last personal impression, confesses that the reading of the fifth chapter of the second part of Dostoevsky's Brothers Karamazov makes him cry in spite of himself. Seeking an explanation, the only one he can come up with is that it is not the ethical or political content of Ivan's speech that moves him, but the rhetoric, more precisely "the voice of Ivan as realized by Dostoevsky" (225).

Diary of a Bad Year is a textual arena in which different forms of writing are played out against one another through different narrative instances in an attempt to test the question of authorship and identity in language. To probe into the quandaries, mysteries and absurdities of life is for the writer just as strong an ethical demand as testing his capacity to imaginatively enter into others' life experiences, however alien and remote they may be. Be it the work of an essayist or of a writer, Coetzee's novel attempts to explore to the limits the burden of being a writer. Its fragmented composition, the plurality of its narrative instances are pitted against something else: the confrontation with the enigmatic, the unknown or unknowable. In one of the essays which boils down to a kind of mise en abyme, the narrator wonders whether all languages are not after all "foreign languages alien to our animal being. But in a way inarticulate, inarticulable" (197). Derek Attridge's remark about the fiction of Elizabeth Costello could equally well apply to Diary of a Bad Year when he notes that this form of writing "is a means toward a profound self-examination on the part of Coetzee, a testing of, and by, the obligations and temptations faced by the literary writer," and, he further adds, "Coetzee pursues the difficult path [...] with its dark exploration of the cost of fictional creation" (Attridge 200).

Richard SAMIN Nancy-Université

\section{Works Cited}

Attridge, Derek. J.M. Coetzee and the Ethics of Reading. Chicago and London: $\mathrm{U}$ of Chicago P, 2004.

Benveniste, Emile. Problèmes de linguistique générale. Vol. 1. Paris : Gallimard, 1966. 2 volumes.

Coetzee, J.M. "Achterberg's 'Ballade van de Gasfitter': The Mystery of I and You”, in 
David Attwell, ed. Doubling the Point, Essays and Interviews. Cambridge, Mass. and London: Harvard UP, 1992. 69-90.

"A Note on Writing (1984)", in David Attwell, ed. Doubling the Point, Essays and Interviews. Cambridge, Mass. and London: Harvard UP, 1992. 94-95.

—. Diary of a Bad Year. London: Harville Secker, 2007.

-. Doubling the Point. Essays and Interviews. David Attwell, ed. Cambridge, Mass. and London: Harvard UP, 1992.

—. Elizabeth Costello. London: Secker and Warburg, 2003.

—. Foe. London: Secker and Warburg, 1986.

-. Giving Offense. Essays on Censorship. Chicago and London: U of Chicago P, 1996.

—. Stranger Shores. Essays 1986-1999. London: Secker and Warburg, 2001.

—. "He and His Man". (December 7, 2003).

<http://nobelprize.org/nobel_prizes/literature/laureates/2003/coetzee-lecture-e.html> (7 June 2009).

—. The Lives of Animals. London: Princeton UP, 1999.

Deleuze, Gilles. Critique et clinique. Paris : Les Editions de Minuit, 1993.

Wood, James. "J.M. Coetzee's Diary of a Bad Year". The New Yorker (December 24, 2007).

<http:www.newyorker.com/arts/critics/books/2007/12/24/071224crbo_books_wood> (3 January 2009). 